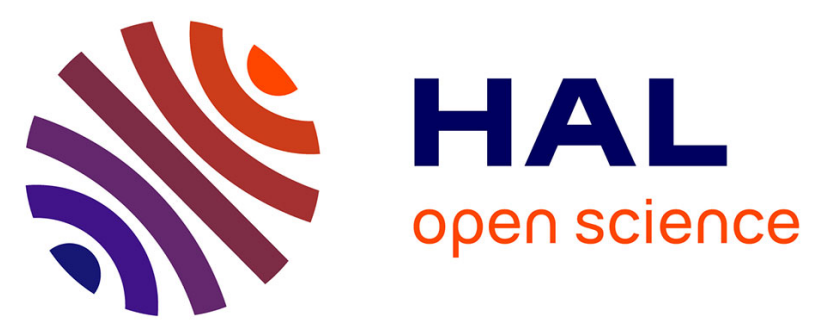

\title{
Integrating hydrological features and genetically validated occurrence data in occupancy modeling of an endemic and endangered semi-aquatic mammal species, Galemys pyrenaicus, in a Pyrenean catchment
}

Anaïs Charbonnel, Laetitia Buisson, Marjorie Biffi, Frank d'Amico, Aurélien Besnard, Stéphane Aulagnier, Frédéric Blanc, François Gillet, Vincent Lacaze, Johan R. Michaux, et al.

\section{- To cite this version:}

Anaïs Charbonnel, Laetitia Buisson, Marjorie Biffi, Frank d'Amico, Aurélien Besnard, et al.. Integrating hydrological features and genetically validated occurrence data in occupancy modeling of an endemic and endangered semi-aquatic mammal species, Galemys pyrenaicus, in a Pyrenean catchment. Biological Conservation, 2015, 184, pp.182-192. 10.1016/j.biocon.2015.01.019 . hal-01494960

\author{
HAL Id: hal-01494960 \\ https://hal.science/hal-01494960
}

Submitted on 24 Mar 2017

HAL is a multi-disciplinary open access archive for the deposit and dissemination of scientific research documents, whether they are published or not. The documents may come from teaching and research institutions in France or abroad, or from public or private research centers.
L'archive ouverte pluridisciplinaire HAL, est destinée au dépôt et à la diffusion de documents scientifiques de niveau recherche, publiés ou non, émanant des établissements d'enseignement et de recherche français ou étrangers, des laboratoires publics ou privés. 


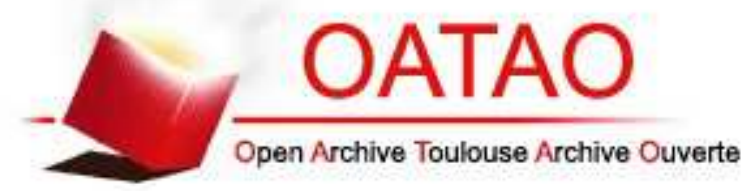

\section{Open Archive TOULOUSE Archive Ouverte (OATAO)}

OATAO is an open access repository that collects the work of Toulouse researchers and makes it freely available over the web where possible.

This is an author-deposited version published in : http://oatao.univ-toulouse.fr/ Eprints ID : 10564

To link to this article : DOI : 10.1016/j.biocon.2015.01.019

URL : http://dx.doi.org/10.1016/j.biocon.2015.01.019

\footnotetext{
To cite this version : Charbonnel, Anaïs and Buisson, Laetitia and Biffi, Marjorie and D'Amico, Frank and Besnard, Aurélien and Aulagnier, Stéphane and Blanc, Frédéric and Gillet, François and Lacaze, Vincent and Michaux, Johan R. and Némoz, Mélanie and Pagé, Christian and Sanchez-Pérez, José-Miguel and Sauvage, Sabine and Laffaille, Pascal Integrating hydrological features and genetically validated occurrence data in occupancy modeling of an endemic and endangered semi-aquatic mammal species, Galemys pyrenaicus, in a Pyrenean catchment.(2015) Biological Conservation, vol. 184. pp. 182-192. ISSN 0006-3207
}

Any correspondence concerning this service should be sent to the repository administrator: staff-oatao@ listes-diff.inp-toulouse.fr 


\title{
Integrating hydrological features and genetically validated occurrence data in occupancy modelling of an endemic and endangered semi-aquatic mammal, Galemys pyrenaicus, in a Pyrenean catchment
}

\author{
Anaïs Charbonnel ${ }^{\mathrm{a}, \mathrm{b}, \mathrm{c}, *}$, Laëtitia Buisson ${ }^{\mathrm{b}, \mathrm{c}}$, Marjorie Biffi ${ }^{\mathrm{b}, \mathrm{c}}$, Frank D’Amico ${ }^{\mathrm{d}, \mathrm{e}}$, Aurélien Besnard ${ }^{\mathrm{f}}$, \\ Stéphane Aulagnier ${ }^{\mathrm{g}}$, Frédéric Blanc ${ }^{\mathrm{a}}$, François Gillet ${ }^{\mathrm{a}, \mathrm{h}}$, Vincent Lacaze ${ }^{\mathrm{i}}$, Johan R. Michaux ${ }^{\mathrm{h}}$, \\ Mélanie Némoz ${ }^{\mathrm{a}}$, Christian Pagé ${ }^{\mathrm{j}}$, José Miguel Sanchez-Perez ${ }^{\mathrm{b}, \mathrm{k}}$, Sabine Sauvage ${ }^{\mathrm{b}, \mathrm{k}}$, Pascal Laffaille ${ }^{\mathrm{b}, \mathrm{k}}$ \\ ${ }^{a}$ Conservatoire d'Espaces Naturels Midi-Pyrénées, 75 voie du TOEC, BP 57611, 31076 Toulouse, France \\ ${ }^{\mathrm{b}}$ CNRS, UMR 5245, CNRS, EcoLab (Laboratoire Ecologie Fonctionnelle et Environnement), 31326 Castanet-Tolosan, France \\ ${ }^{\mathrm{c}}$ Université de Toulouse, INP, UPS, EcoLab (Laboratoire Ecologie Fonctionnelle et Environnement), 118 Route de Narbonne, 31062 Toulouse, France \\ ${ }^{\mathrm{d}}$ Université de Pau et des Pays de l'Adour, UFR Sciences E' Techniques Côte Basque, Campus Montaury, 64600 Anglet, France \\ ${ }^{\mathrm{e}}$ Université de Pau, Laboratoire de Mathématiques et de leurs Applications, LMAP CNRS-UMR 5142, Av. de l'Université, 64000 Pau, France

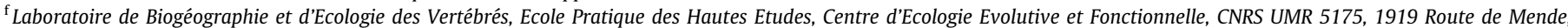 \\ 34293 Montpellier Cedex 5, France \\ ${ }^{\mathrm{g}}$ INRA, UR 0035 CEFS Comportement et Ecologie de la Faune Sauvage. Centre de recherche de Toulouse, 31320 Auzeville, France \\ ${ }^{\mathrm{h}}$ Génétique des Microorganismes, Dépt des Sciences de la Vie, Univ. de Liège, Inst. De Botanique B22, BE-4000 Liège, Belgium \\ ${ }^{\mathrm{i}}$ Association des Naturalistes d'Ariège Vidallac, 09240 Alzen, France \\ ${ }^{\mathrm{j} S}$ Sciences de l'Univers au CERFACS, URA 1875, CERFACS/CNRS, 42 Avenue Gaspard Coriolis, 31057 Toulouse Cedex 01, France \\ ${ }^{\mathrm{k}}$ Université de Toulouse, INP, UPS, EcoLab (Laboratoire Ecologie Fonctionnelle et Environnement), ENSAT, Avenue de l'Agrobiopole, 31326 Castanet-Tolosan, France
}

Keywords:

Pyrenean desman

Detection

Markovian site occupancy model

Habitat use

Soil and water assessment tool

\begin{abstract}
A B S T R A C T
As freshwater habitats are among the most endangered, there is an urgent need to identify critical areas for conservation, especially those that are home to endangered species. The Pyrenean desman (Galemys pyrenaicus) is a semi-aquatic mammal whose basic ecological requirements are largely unknown, hindering adequate conservation planning even though it is considered as a threatened species. Species distribution modelling is challenging for freshwater species. Indeed, the complexity of aquatic ecosystems (e.g., linear and hierarchical ordering) must be taken into account as well as imperfect sampling. High-quality and relevant hydrological descriptors should also be used. To understand the influence of environmental covariates on the occupancy and detection of the Pyrenean desman, we combine both a robust sign-survey data set (i.e. with genetic validation ensuring true presence information) and a hydrological model to simulate the flow regime across a whole catchment. Markovian site-occupancy analysis, taking into account sign detection and based on spatially adjacent replicates, indicated a positive influence of heterogeneity of substrate and shelters, and a negative influence of flow variability on Pyrenean desman detection. This valuable information should help to improve monitoring programs for this endangered species. Our results also highlighted a spatially clustered distribution and a positive influence of stream flow and number of tributaries on occupancy. Hence, modifications of flow regime (e.g. hydropower production, irrigation, climate change) and habitat fragmentation appear to be major threats for this species, altering the connectivity between tributaries and the mainstream river as well as between adjacent sub-catchments.
\end{abstract}

\footnotetext{
* Corresponding author at: Université Paul Sabatier, Bât. 4R1, 118 route de Narbonne, 31062 Toulouse, France. Tel.: +33 (0)5 61558912.

E-mail addresses: anais.charbonnel@espaces-naturels.fr (A. Charbonnel), laetitia. buisson@univ-tlse3.fr (L. Buisson), m.biffi@live.fr (M. Biffi), Frank.Damico@ univ-pau.fr (F. D’Amico), aurelien.besnard@cefe.cnrs.fr (A. Besnard), stephane. aulagnier@toulouse.inra.fr (S. Aulagnier), frederic.blanc@espaces-naturels.fr (F. Blanc), francois.gillet@espaces-naturels.fr (F. Gillet), vincent.1@ariegenature.fr (V. Lacaze), michaux@supagro.inra.fr (J.R. Michaux), melanie.nemoz@espacesnaturels.fr (M. Némoz), christian.page@cerfacs.fr (C. Pagé), jose-miguel.sanchezperez@univ-tlse3.fr (J.M. Sanchez-Perez), sabine.sauvage@univ-tlse3.fr (S. Sauvage), pascal.laffaille@ensat.fr (P. Laffaille).
}

\section{Introduction}

Freshwater habitats hold a notable biodiversity with for example, one third of vertebrate species being restricted to this ecosystem (Dudgeon et al., 2006). However, freshwater habitats are one of the most endangered ecosystems in the world (Vörösmarty et al., 2010) and human-induced alterations of the natural river conditions strongly affect aquatic biodiversity 
(Dudgeon et al., 2006; Vörösmarty et al., 2010). Extinction rates of freshwater fauna are currently extremely high (Allan et al., 2005) with around 15,000 freshwater species worldwide already extinct or imperiled as a result of human activity (Strayer and Dudgeon, 2010). As a consequence, there is an urgent need to identify critical areas for conservation of freshwater biodiversity especially for rare, endemic and endangered species.

Among rare freshwater species, the Pyrenean desman (Galemys pyrenaicus) is one of the less well-known European mammals. The distribution of this small semi-aquatic species is restricted to the Pyrenees (Andorra, France and Spain), as well as parts of northern and central Spain and northern Portugal. In the French Pyrenees, the species lives in mountain brooks, cold and well oxygenated water courses from sea level to $2700 \mathrm{~m}$ (Némoz et al., 2011). The Pyrenean desman is becoming increasingly threatened, triggering several conservation regulations (Fernandes et al., 2008). Yet, even basic knowledge such as distribution range and habitat preferences that are essential for conservation planning are not complete for this species (Aymerich, 2004; Barbosa et al., 2009, 2010; Nores et al., 1992, 1999; Palmeirim et al., 1983; Queiroz et al., 1996).

The environmental factors influencing the spatial distribution of species can be identified by the use of Species Distribution Models (SDMs). They model the statistical relationships between species presence records and environmental variables, and may be used to predict habitat suitability for species in unsampled areas (Guisan and Zimmermann, 2000). A few studies have used SDMs for understanding the ecological requirements of the Pyrenean desman and have reported a positive influence of topographic variability, and a strong but contrasting influence of climatic variables, depending on the study area (Barbosa et al., 2009; Morueta-Holme et al., 2010; Williams-Tripp et al., 2012). A negative effect of the density of urban areas was also identified (Barbosa et al., 2009). As these studies were applied at large scales (e.g., the whole Iberian Peninsula) and with coarse resolution (e.g., $10 \mathrm{~km}$ ), they did not take into account the particular features of freshwater environments.

Indeed, SDMs for aquatic species often fail to account fully for links between organism occurrence and environmental constraints imposed by river networks (Jähnig et al., 2012) as they do not take into account the linear configuration of the river network (SDMs built on grid cells with both aquatic and terrestrial ecosystems considered together; e.g. Blank and Blaustein, 2012; Domisch et al., 2013). Not accounting for these particular features seems to be appropriate for broad-scale studies as the use of climatic or topographic variables might be more meaningful (Bucklin et al., 2015). As aquatic species' movements are constrained by the spatial orientation of the watercourses and by the connectivity between streams and sub-catchments, such hydrological parameters should however be considered (Ottaviani et al., 2009), especially for small-scale predictions (e.g. across a river catchment). The importance of hydrological variables on freshwater species ecology and distribution is well known (e.g. Kuemmerlen et al., 2014) even for river birds (Royan et al., 2014) or semi-aquatic mammals (Pedroso et al., 2014; Toner et al., 2010). Despite this, hydrological variables (e.g. stream flow) are often ignored in SDMs due to the lack of fine scale spatial data available for studies conducted in large areas. A solution to counterbalance this lack of data may be to simulate flow variables using a hydrological model. One of the most commonly applied, the Soil and Water Assessment Tool (SWAT), is a catchment-scale, physically based model (Arnold et al., 1998), running on a daily time step and capable of continuous simulation over a long time period at different spatial scales (Gassman et al., 2007). By using spatial information (i.e. topography, climate, soil and land-use), SWAT simulates the hydrological cycle both in space and time (see Neitsch et al., 2005 for more details). To our knowledge, very few studies have coupled this tool with SDMs to understand the influence of hydrological parameters on the presence of aquatic species, and to predict habitat suitability (but see Jähnig et al., 2012; Kuemmerlen et al., 2014).

Another important challenge in SDMs is the quality of species presence-absence data. When surveys are based on the recording of indirect signs, such as faeces, ambiguous signs could lead to the risk of species misidentification, leading to false presences (i.e. wrongly attributed to the species of interest; Miller et al., 2011) or false absences (i.e. wrongly attributed to species other than the species of interest). To overcome this issue, techniques that identify species using faecal DNA analysis are increasingly used (Waits and Paetkau, 2005). Species detection is another major issue. It is well known that the absence of records in the field is a combination of undetected presences (i.e. false absences) and true absences (Gu and Swihart, 2004). Semi-aquatic mammals, such as the Pyrenean desman, are particularly sensitive to this detection issue as monitoring is usually based on faeces searches in heterogeneous environments (González-Esteban et al., 2003). Site occupancy models have been developed to deal with species detection issues at a large scale. They model the probability that a species occupies some sites even though the species has not been detected with any certainty when the sites were visited (MacKenzie et al., 2002). This class of models requires replication of detection-non detection data at sampling sites. Usually based on temporal replication, recent developments of site occupancy models now allow the use of spatial instead of temporal replicates. Among them, the Markovian occupancy model can be applied when spatially adjacent replicates are available at sites, to test for spatial correlation of occupancy probabilities between replicates (Charbonnel et al., 2014; Hines et al., 2010). To date, this recent model has rarely been applied to investigate the influence of covariates on species distribution (see however Barber-Meyer et al., 2013; Karanth et al., 2011; Thorn et al., 2011).

In this study, we applied the Markovian occupancy model to a genetically validated dataset for the Pyrenean desman, and used a hydrological model to simulate flow in the river network of a single catchment in the French Pyrenees. Our aim was to highlight the environmental factors, including hydrological variables, influencing detection and occupancy of this threatened semi-aquatic species for better implementation of conservation plans.

\section{Methods}

\subsection{Study area}

The upper river Salat $\left(42-43^{\circ} \mathrm{N}, \quad 0-1^{\circ} \mathrm{W}\right.$; drainage area $=1156 \mathrm{~km}^{2}$ ) is a tributary of the river Garonne, located in the French Pyrenean Mountains (Fig. 1). This catchment has a stream length of $1388 \mathrm{~km}$ (CARTHAGE $\odot$ DB, French database on thematic mapping of the Water Agencies, 2011 version http:// www.sandre.eaufrance.fr). Elevation varies between 350 and $2870 \mathrm{~m}$ (mean elevation $=1200 \mathrm{~m}$ ). Mean $( \pm \mathrm{sd})$ annual rainfall, air temperature and stream flow are $1360.83 \mathrm{~mm} \pm 216.72$ (range $=1013.72-1998.49), \quad 9.51^{\circ} \mathrm{C} \pm 1.76 \quad$ (range $=4.21-12.11$; Pagé and Terray, 2010) and $0.78 \mathrm{~m}^{3} / \mathrm{s} \pm 2.76$ (range $=0.00-31.96$; SWAT simulations, see 2.4 ), respectively. Land cover (Corine Land Cover $\odot$ DB, map of the European environmental landscape, version 2006) is dominated by forests (50\%) and herbaceous and shrubby vegetation (25\%). We focused our study on this catchment because of (i) its representativeness of other French Pyrenean catchments, (ii) its conservation status (this catchment is part of a Natura 2000 site) and (iii) the known presence of Pyrenean desman (Bertrand, 1994). The stream network (CARTHAGE $\odot$ DB) was 


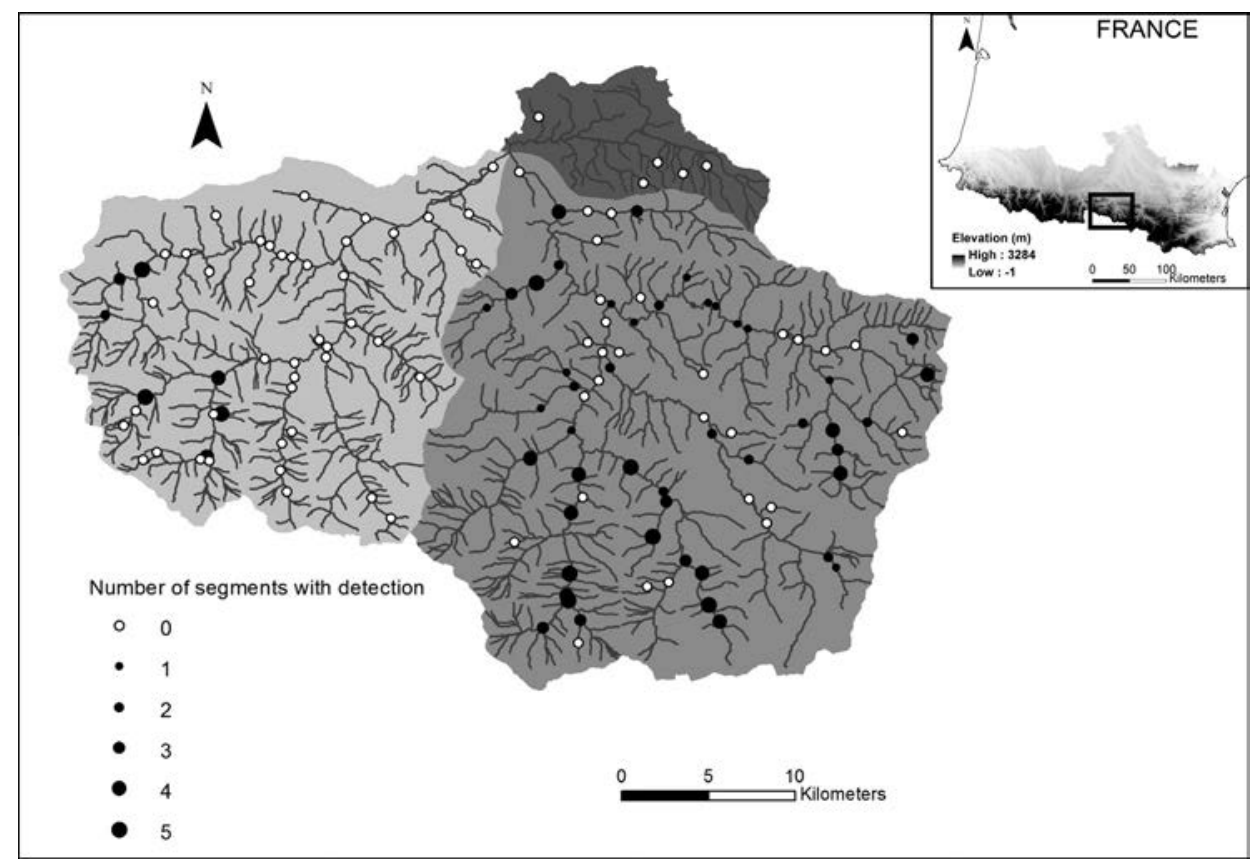

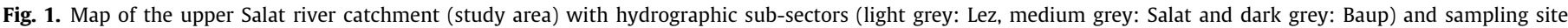
locations (dots, $n=131$ ). The size of dots indicates the number of segments with detection for each site.

divided into 1388 1-km-long sections (hereafter simply called sections) for the computation of environmental covariates.

\subsection{Field sampling}

One hundred thirty-one sites (i.e. river transects) were surveyed for this study (Fig. 1). Sites were selected using a spatially balanced, Generalized Random Tessellation Stratified sampling which is known to produce survey designs suitable for aquatic systems (Stevens and Olsen, 2004). Searches for Pyrenean desman faeces were conducted along these river transects which were waded by pairs of skilled observers, meticulously inspecting each emergent rock, tree root or branch in the riverbed (i.e. river banks were not inspected). The number of observers was limited as much as possible across transects to minimize observer bias for sign detection. All faeces detected and suspected of being left by a Pyrenean desman based on colour, size, and position were harvested for genetic analysis. Surveys were conducted between 2011 and 2013 during the summer, when faeces appeared to persist longest, to maximize detection (Bertrand, 1994). We tried not to conduct surveys during or after a period of fluctuating water levels or heavy rainfall to minimize variations in sign detection probabilities (e.g., removal of faeces by rising water levels). Each site was a riverbed transect $500 \mathrm{~m}$-long, which approximately matches the mean home range of the species (Melero et al., 2012). Each site was divided into five sub-units (i.e. segments) of equal length (i.e. $100 \mathrm{~m}$ ) that constituted adjacent spatial replicates, as this segment length appears appropriate for the Pyrenean desman when analyzed with the Markovian occupancy model (Charbonnel et al., 2014). For each segment, information of detection or non-detection of faeces was thus available.

\subsection{Genetic validation of faeces identification}

Genomic DNA from faeces samples was extracted using the Stool Mini Kit (Qiagen Inc., Hilden, Germany). DNA extraction was conducted in a separate room with a UV-sterilised platform where no Pyrenean desman tissue samples had previously been treated. In order to identify the owner species of the faeces sample, we amplified a small cytochrome b fragment of approximately 400 bp using specific primers designed for this study (GPYRF1: 5'-TTGTAGAATGGAKCTGAGG-3', GPYRF2: 5'-TTCCTTCACGAAACAGGATC-3' and GPYRR1: 5'-GTCGGCTGCTAAAAGTCAGAATA-3'). PCRs were carried out in a volume of $9 \mu \mathrm{l}$ containing $0.17 \mu \mathrm{l}$ of forward primer GPYRF1 and $0.17 \mu$ l of reverse primer GPYRR1 $(10 \mu \mathrm{M}), 2.89 \mu \mathrm{l}$ of sterile water, $0.58 \mu \mathrm{l}$ of dNTPs $(10 \mu \mathrm{M})$, $1.70 \mu \mathrm{l}$ of $\mathrm{MgCl}_{2}(25 \mathrm{mM}), 3.40 \mu \mathrm{l}$ of $5 \mathrm{X} \mathrm{GoTaq}{ }^{\circledR}$ buffer reaction (Promega Inc., Madison, USA), $0.09 \mu$ l of GoTaq ${ }^{\circledR}$ DNA polymerase (Promega Inc., Madison, USA) and $8 \mu$ lof DNA. Amplifications were performed in a thermal cycler VWR Unocycler using one activation step at $94{ }^{\circ} \mathrm{C}$ for $5 \mathrm{~min}$ followed by 40 cycles (denaturation at $94{ }^{\circ} \mathrm{C}$ for $50 \mathrm{~s}$, annealing at $52{ }^{\circ} \mathrm{C}$ for $45 \mathrm{~s}$, extension at $72{ }^{\circ} \mathrm{C}$ for $45 \mathrm{~s}$ ) and final extension step at $72^{\circ} \mathrm{C}$ for $10 \mathrm{~min}$. Three microlitres of the PCR product were amplified in a nested PCR with $14 \mu \mathrm{l}$ of the PCR mixture described above with additions of $5 \mu$ of sterile water and $0.17 \mu \mathrm{l}$ of forward primer GPYRF2 $(10 \mu \mathrm{M})$ in place of GPYRF1. PCR products were sequenced on an Applied Biosystems ${ }^{\circledR} 3730$ DNA analyzer and verified using CHROMASPRO v 1.5 (http://technelysium.com.au). Sequences were then submitted to the BLAST ${ }^{\circledR}$ functionality available on the NCBI website (http://blast.ncbi.nlm. nih.gov). For a detailed description of the protocol, see Gillet et al. (in press).

\subsection{Simulation of stream flow using SWAT model}

The combined use of hydraulic and distribution models involves hydrological information available at the same spatial resolution (here, 1-km river sections). SWAT requires several input datasets using the ArcSWAT interface in ArcGIS 10.0 (Winchell et al. 2007). SWAT uses a topography map to delineate the watershed that was divided into 1165 sub-basins (mean surface area $=100$ ha \pm 82 ; mean reach length $=873 \mathrm{~m} \pm 704$ ) with a discretization scale of 50 ha (Fig. 2). In this study, we used (i) a $25 \mathrm{~m}$ resolution Digital Elevation Model (ALTI (c) DB - IGN), (ii) a $1 \mathrm{~km}$ resolution Digital Soil Map of the World (FAO, 2007), and (iii) a $250 \mathrm{~m}$ resolution land cover map (BDOS ㄷ, Regional Natural 


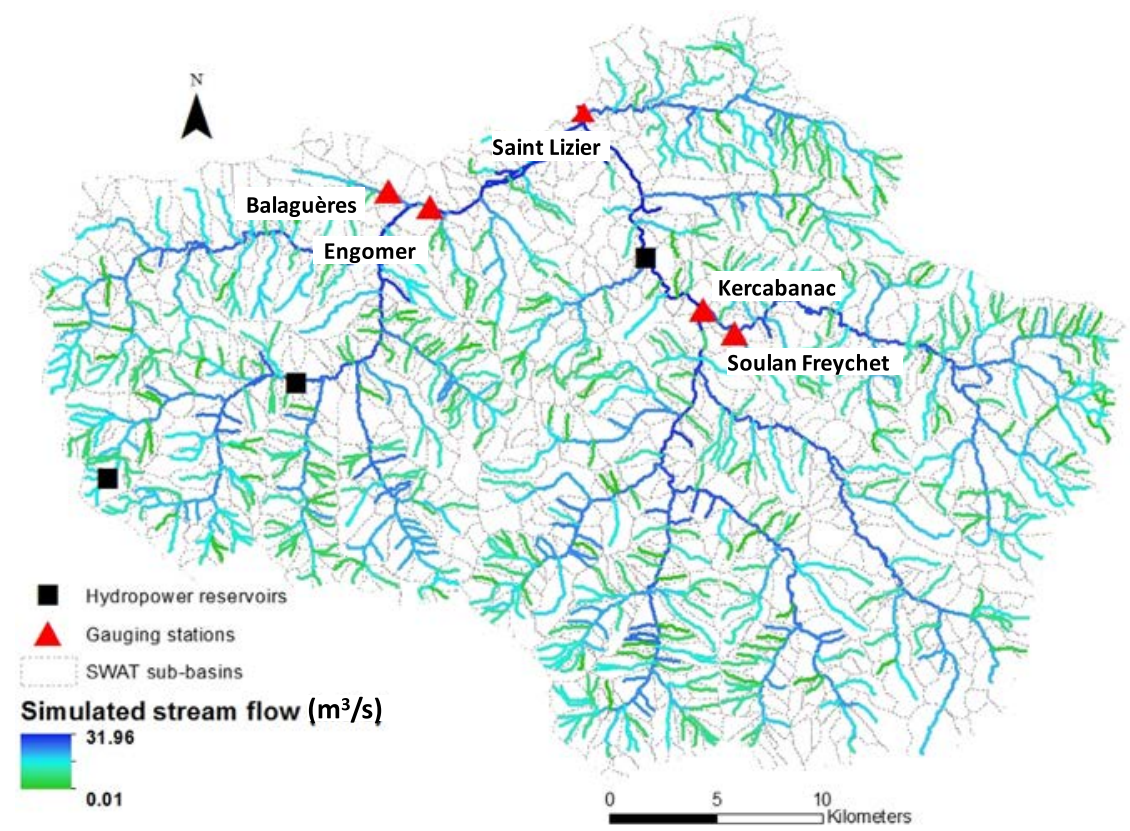

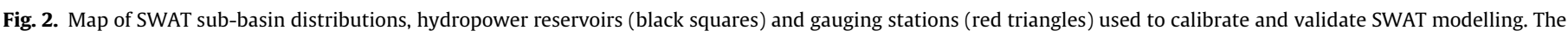

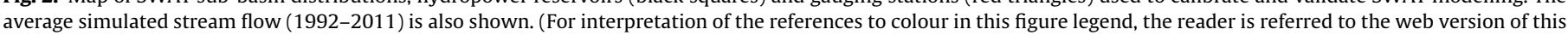
article.)

Parks of Midi-Pyrénées). The climatic variables used to calibrate the SWAT models included daily rainfall, maximum and minimum air temperature, solar radiation, wind speed and relative humidity. Climatic variables were derived from the SAFRAN (C) DB (19922011) which has a spatial resolution of $8 \mathrm{~km}$ and accounts for the influence of the topography on the atmospheric variables (Habets et al., 2008). As our study area was located in a mountainous region, we modified snow parameters to calibrate SWAT and improved flow simulations (Appendix A, Supplementary Materials). Observed monthly output flows of three hydropower reservoirs (Fig. 2; Electricity of France) were also included in simulations to increase their accuracy. After running SWAT, simulated stream flows were available in the 1165 sub-basins with a monthly time step, between 1992 and 2011. For each of the 1388 1-km sections, the flow value assigned was that of the sub-basin it was included in. A simulation period of 20 years was chosen to reduce the influence of years with extreme hydrological events (e.g. flood, low water). Average monthly stream flow data recorded from 1992 to 2011 were available at five gauging stations (Fig. 2) and used to calibrate and evaluate the performance of the SWAT simulations using three different metrics: the Spearman correlation coefficient (rho), the coefficient of determination $\left(R^{2}\right)$ and the Nash-Sutcliffe Efficiency (NSE) calculated between measured and simulated stream flow (e.g. Kiesel et al., 2010; Moriasi et al., 2007). As is typically done (Qi and Grunwald, 2005), the model was calibrated using the gauging station located at the outlet ("Saint-Lizier") and validated at the four other gauging stations (Fig. 2).

\subsection{Covariates influencing detection and occupancy}

\subsubsection{Covariates related to detection probability}

Bias in sign detection may arise due to a variety of factors including weather, habitat structure and observer. First, species detection is known to be influenced by the experience of the observer (MacKenzie et al., 2006). Hence, we used the pairs of observers who inspected each transect as a first covariate (OBS; 3 categories). For the Pyrenean desman, we then hypothesized that substrate heterogeneity influences faeces detection as emergent items are supports for faeces deposits. We could expect that the greater the heterogeneity, the higher the detection. Hence, during sampling, observers visually assessed the percentage of heterogeneity of substrate and shelters (e.g. rocks, tree roots or branches) in the riverbed (SUBSTRATE) that was classified in four categories: $0-25 \%, 26-50 \%, 51-75 \%$ and $76-100 \%$. The $0-25 \%$ category indicated a riverbed with homogeneous substrate and few or no shelters whereas the $76-100 \%$ category indicated a riverbed with a very high diversity of substrate and shelters (e.g. rocks, tree roots or branches). In addition, rainfall may negatively influence the faeces detection by washing out emergent items, as already shown for the European otter (Lutra lutra; Reid et al., 2013). It could thus be more difficult to find faeces in areas with high annual rainfall as items are regularly washed out. Flow variability might also influence detection with higher variation in stream flow resulting in faeces regularly removed by the fluctuating water level, and thus a lowered detection. Consequently, we used the mean annual rainfall (RAIN, mean of the annual rainfall from 1992 to 2011, mean across the 131 river transects $=1252.80 \mathrm{~mm} \pm 154.75)$ and the inter-monthly flow variability (FLOW VAR, variance of the twelve monthly flows simulated from SWAT, averaged from 1992 to 2011 , mean $=1.81 \pm 7.40$ ). All these covariates were calculated for each $1-\mathrm{km}$ section.

\subsubsection{Covariates related to occupancy probability}

We used four covariates that were not highly correlated $(|r| \leqslant 0.60)$ in the Markovian occupancy model. First, we used the mean monthly flow (FLOW, mean of the twelve monthly flows, averaged from 1992 to 2011, simulation of SWAT models, mean $=1.48 \mathrm{~m}^{3} / \mathrm{s} \pm 2.76$ ). Second, we calculated eight climatic covariates over the period 1992-2011 (Pagé and Terray, 2010): the mean ( \pm sd) annual temperature $\left(10.4{ }^{\circ} \mathrm{C} \pm 1.34\right)$, the mean temperature of the coldest month $\left(2.38^{\circ} \mathrm{C} \pm 1.23\right)$, the mean temperature of the warmest month $\left(18.74{ }^{\circ} \mathrm{C} \pm 1.32\right)$, the inter-annual temperature variability $(32.39 \pm 6.17)$, the mean annual rainfall $(1253 \mathrm{~mm} \pm 1.55)$, the mean rainfall of the driest month $(32.33 \mathrm{~mm} \pm 4.57)$, the mean rainfall of the wettest month 
$(214.4 \mathrm{~mm} \pm 2.41)$ and the inter-annual rainfall variability $(359.50 \pm 9.76)$. As they were quite strongly correlated $(|r| \geqslant 0.72)$, we used the first axis of a principal component analysis (PCA) which explained $93.80 \%$ of the variation of the climatic covariates as a synthetic covariate (CLIMATE). Its values increased as mean annual rainfall increased while mean annual temperature decreased. For both FLOW and CLIMATE, linear and quadratic terms were included in occupancy models. Third, we calculated the number of tributaries (TRIBUTARIES, derived from CARTHAGE (C) $\mathrm{DB}$, mean $=3.11 \pm 1.99$ ) for each $1-\mathrm{km}$ section and its proximal upstream and downstream sections. Finally, the influence of the three main hydrographic sub-sectors was also tested (SUB-SECTOR; 3 categories; CARTHAGE $\odot$ DB; Fig. 1). To improve the convergence of occupancy models, all non-categorical covariates were log-transformed and normalized.

\subsection{Data analysis}

We applied to our dataset the Markovian occupancy model recently developed by Hines et al. (2010) which estimated four parameters: $p$, the probability of detecting the species conditional on the presence of the species on the site (i.e. probability of detection); $\psi$, the probability that a site is occupied or used by a species (i.e. probability of site occupancy); $\theta_{0}$, the probability that a species is present on a segment given that the site is occupied but the species was absent on the previous adjacent segment; and $\theta_{1}$, the probability that a species is present on the segment given that the site is occupied and that the species was present on the previous adjacent segment (see Charbonnel et al., 2014, and Hines et al., 2010 for more details about the parameters estimated).

To evaluate the predictive accuracy of our final model predictions, we used a jackknife iterative procedure, best suited for small data sets $(n=131)$ than the traditional partitioning in $70 \%$ for calibration and $30 \%$ for validation. Thus, the model selection process described below was repeated 131 times. This model selection process initially focused on determining a suitable covariates model structure for detection $(p)$ and subsequently used this model structure to test combinations of covariates for occupancy $(\psi)$. We first defined a full occupancy model (i.e. including all four occupancy covariates) based on the recommendations of Burnham and Anderson (2002) and MacKenzie et al. (2006). Then, we formulated covariates for detection, either without any covariates, or individually or in additive combination, restricting models to a maximum of two covariates to reduce convergence problems (Burnham and Anderson, 2002). This resulted in eleven different models. All model comparisons were based on Akaike Information Criterion (AIC) values (Burnham and Anderson, 2002). The Akaike weights $(\omega i)$ were also calculated. To assess the relative importance of each detection covariate, the sum of $\omega i$ of models $(\Sigma \omega i)$ that included each covariate was calculated. As this process was repeated 131 times (see above), we then summed the Akaike weights obtained for the 131 iterations. Based on this global Akaike weight, the detection covariates were ranked and the ones with the highest rank were selected to fix the model structure for $p$. Thereafter, we kept this model structure component unchanged and ran further occupancy analyses to compare models involving either no covariates or all combinations of covariates for $\psi$, resulting in sixteen models. No covariates were included for local occupancy parameters $\theta_{0}$ and $\theta_{1}$ to reduce the number of parameters to estimate. Like for detection covariates, the global Akaike weight of each occupancy covariate was calculated. For each iteration, model averaging was used to determine the effect size ( $\beta$ regression coefficient) of each covariate across the top set of models ( $\triangle \mathrm{AIC} \leqslant 2$; Burnham and Anderson, 2002). Finally, a global average coefficient was computed for each covariate across the 131 iterations, and used to build covariate response curves for occupancy and detec- tion. Ninety-five percent confidence intervals were calculated through the jackknife procedure. Estimates obtained through model averaging for each iteration were then used to predict occupancy probabilities over the whole Salat catchment. A final prediction map was thus produced through the computation of average probabilities across the 131 iterations. The predictive accuracy was evaluated using the area under the ROC curve (AUC) which is an index of classification accuracy independent of species prevalence and arbitrary threshold effects (Manel et al., 2001). We fitted all the models using the freeware PRESENCE v. 6.2 (Hines, 2006) and R.2.14.1.

\section{Results}

\subsection{Desman detection}

A total of 579 faeces were collected from 94 out of the 131 sampled sites. Sixty-nine percent of these faeces were genetically confirmed to be Pyrenean desman, sampled in 54 sites (i.e. $41 \%$ of sampling sites with at least one detection event during the survey). DNA included in $27 \%$ of the collected faeces was too degraded to accurately identify the author of the faeces. Four percent of the 579 collected faeces were allocated to another species (e.g. $2 \%$ to Neomys spp.). Among the 54 sites where the presence of desman was genetically confirmed, 13 had only one 100-m segment with detection, 11 had two segments with detection, 9 had three segments with detection, 12 had four segments with detection and 9 had all the five segments with detection. Eighty-seven percent of sites with detection were located in the Salat sub-sector, 13\% in the Lez while no presence was recorded in the Baup sub-sector (Fig. 1).

\subsection{SWAT flow simulation}

SWAT simulations of stream flow were accurate, as indicated by the model evaluation statistics computed between measured and simulated monthly stream flow at the gauging station used for calibration (rho $=0.89 ; R^{2}=0.78$; NSE $=0.73$; "Saint Lizier"; Figs. 2 and 3a). According to Moriasi et al. (2007), the evaluation statistics were also considered to be high at the gauging stations used for the validation step $\quad\left(0.85 \leqslant\right.$ rho $\leqslant 0.91 ; \quad 0.62 \leqslant R^{2} \leqslant 0.85$; $0.60 \leqslant \mathrm{NSE} \leqslant 0.8 ; \quad$ Fig. $3 \mathrm{c}-\mathrm{e})$, except the Balaguères station (rho $=0.81 ; \quad R^{2}=0.50 ; \quad \mathrm{NSE}=0.33 ; \quad$ Fig. $3 \mathrm{~b}$ ). Simulated mean monthly flow over the 1992-2011 period ranges spatially from 0.01 to $31.96 \mathrm{~m}^{3} / \mathrm{s}$, with a mean of $0.78 \mathrm{~m}^{3} / \mathrm{s}$ (Fig. 2).

\subsection{Influence of covariates on detection and occupancy}

The covariate that influenced desman detection most was FLOW VAR (global Akaike weight $=130.56$ ) followed by SUBSTRATE (global Akaike weight $=70.26$ ). OBS had a moderate influence (global Akaike weight $=44.83$ ) while RAIN (global Akaike weight $=0.60$ ) did not explain desman detection at all. To avoid statistical convergence issues when building occupancy models, only the first two covariates, FLOW VAR and SUBSTRATE, were retained. The probability of detecting Pyrenean desman faeces decreased sharply with increasing flow variability (Fig. 4a) and was higher in streams dominated by heterogeneous substrates and shelters in spite of a large variability in detection probabilities for stream reaches with low heterogeneity (Fig. 4b).

For desman occupancy, the covariate SUB-SECTOR exerted the strongest influence (global Akaike weight $=131.00$ ). FLOW was also important (global Akaike weight $=88.99$ ) followed by TRIBUTARIES (global Akaike weight $=76.20$ ) and then CLIMATE (global Akaike weight $=57.07$ ). The Pyrenean desman occupancy was very 

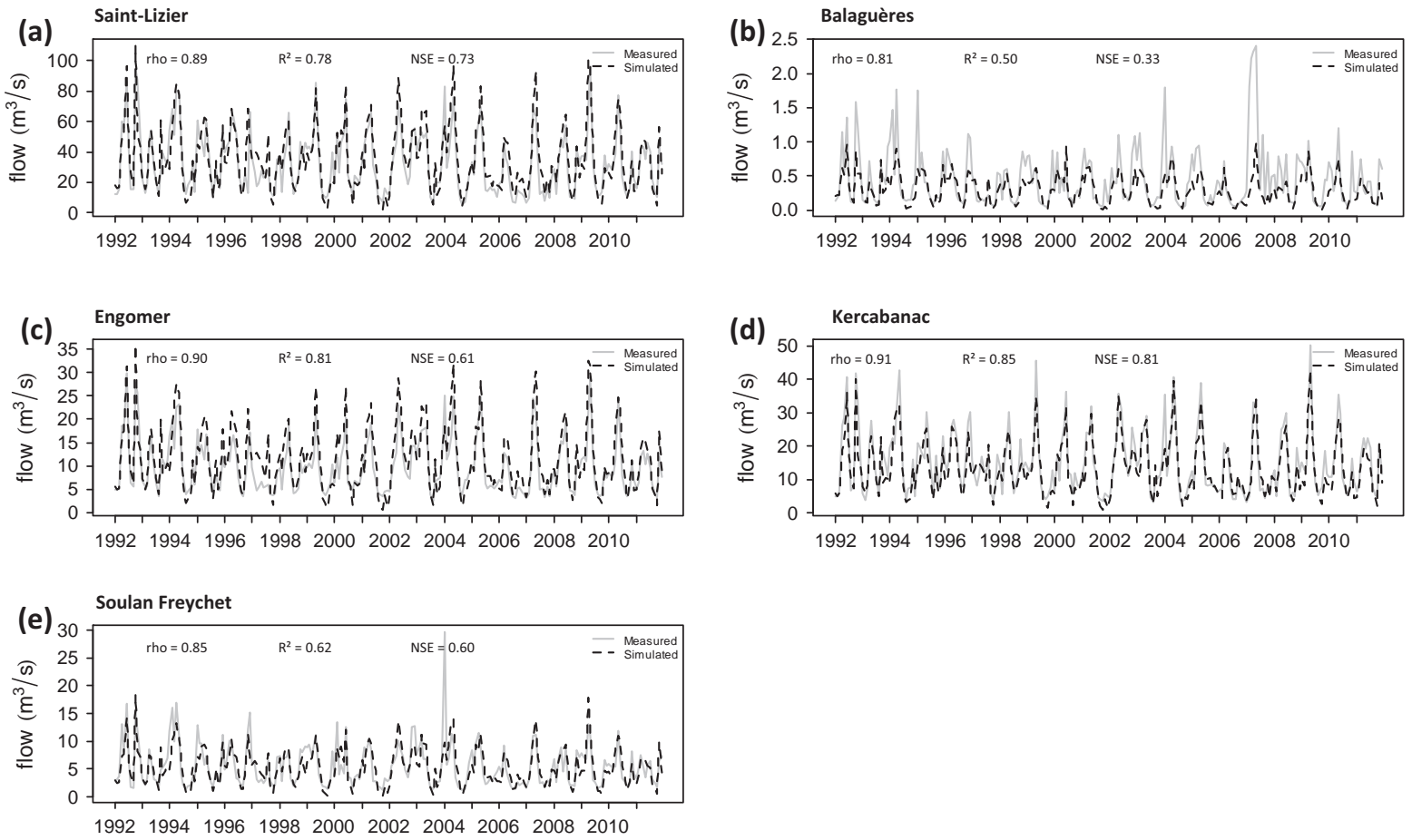

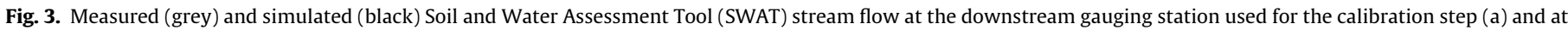

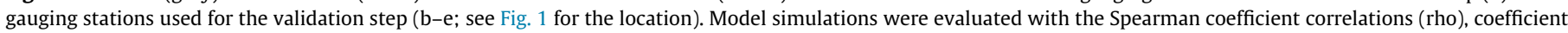
of determination $\left(R^{2}\right)$, and Nash-Sutcliffe efficiency (NSE) between measured and simulated stream flow.

different between sub-sectors with the highest occupancy probabilities for stream sections located in the Salat sub-sector (Figs. 1 and 4c). As no detection event has been reported in the Baup sub-sector (Fig. 1), occupancy probability in this area was estimated to be null by the model. Both covariates FLOW and TRIBUTARIES had a positive influence on occupancy probability (Fig. 4d and e) suggesting that the Pyrenean desman has a higher occupancy probability in stream sections with high mean monthly flow and several tributaries. For example, in the Salat sub-sector, occupancy probability raises rapidly over 0.9 from $5 \mathrm{~m}^{3} / \mathrm{s}$ flow values. Finally, it appears that the Pyrenean desman occupancy was higher in areas with more abundant annual rainfall and colder annual temperature (i.e. high values of CLIMATE; Fig. $4 \mathrm{f}$ ), although this covariate was the least influencing.

Expected local spatial dependence was highlighted by the average model estimates that showed that the probability of Pyrenean desman sign presence on a segment, given absence on the previous segment $\left(\theta_{0}=0.48,95 \% \mathrm{CI}=0.46-0.49\right)$ was lower than the probability of Pyrenean desman sign presence on a segment given presence on the previous segment $\left(\theta_{1}=0.72,95 \% \mathrm{CI}=0.71-0.73\right)$.

\subsection{Predictive occupancy map}

The average predicted occupancy probability for the Pyrenean desman across the study area had a moderate accuracy compared to observations given that AUC value was 0.74 . Occupancy probability estimates ranged from 0 to 0.97 suggesting that some streams are very suitable for the Pyrenean desman while others are not suitable at all in the upper Salat catchment. There was a strong contrast among occupancy probabilities predicted on sections of the three sub-sectors, with a mean occupancy of $0.63 \pm 0.18$ in the Salat, $0.15 \pm 0.12$ in the Lez and $0.00 \pm 0.00$ in the Baup (Figs. 1, 4c and 5a). Higher occupancy probabilities were predicted for major rivers of the Lez and Salat sub-sectors while lower occupancy probabilities were predicted for small tributaries (Fig. 5a), underlining the positive relationship with stream flow.
These predictions indicate a potential linear distribution of $176 \mathrm{~km}(12.5 \%)$ with predicted occupancy probability $\geqslant 0.80$, and $462 \mathrm{~km}(32.7 \%)$ with predicted probabilities $\geqslant 0.60$ in the whole upper Salat river catchment. Last, the area with the highest variability in predicted occupancy across the 131 iterations was located on the Lez river, upstream of the Lez and the Salat confluence, and also in the headwaters of the Lez sub-sector (Fig. 5b).

\section{Discussion}

\subsection{Detection probability of the Pyrenean desman - implications for monitoring}

We have emphasized that the probability of detecting desman faeces decreases in areas with high flow variability, which may regularly submerge emergent items where the desman usually leaves its faeces and thus limit the accumulation of signs. In agreement with Aymerich and Gosàlbez (2004), we thus suggest that periods of heavy rain or high water flow as well as the period shortly following flood events should be avoided when survey involves faeces detection. We also showed that the detection probability rises in streams with a larger diversity of substrate and shelters. This result is consistent with Nores et al. (1992) who suggested that the availability of emergent items may influence the faeces detectability of the Pyrenean desman. When streams with a homogeneous substrate and shelters or high flow variability (natural or artificial) have to be monitored, more efforts in sampling should therefore be directed towards compensating the lowest detection, or other survey methods with higher detection efficiency (e.g. live trapping) should be applied (GonzálezEsteban et al., 2003).

\subsection{Variables influencing occupancy of the Pyrenean desman}

We found that stream flow has a strong and positive influence on the occupancy of the Pyrenean desman. Some authors also 

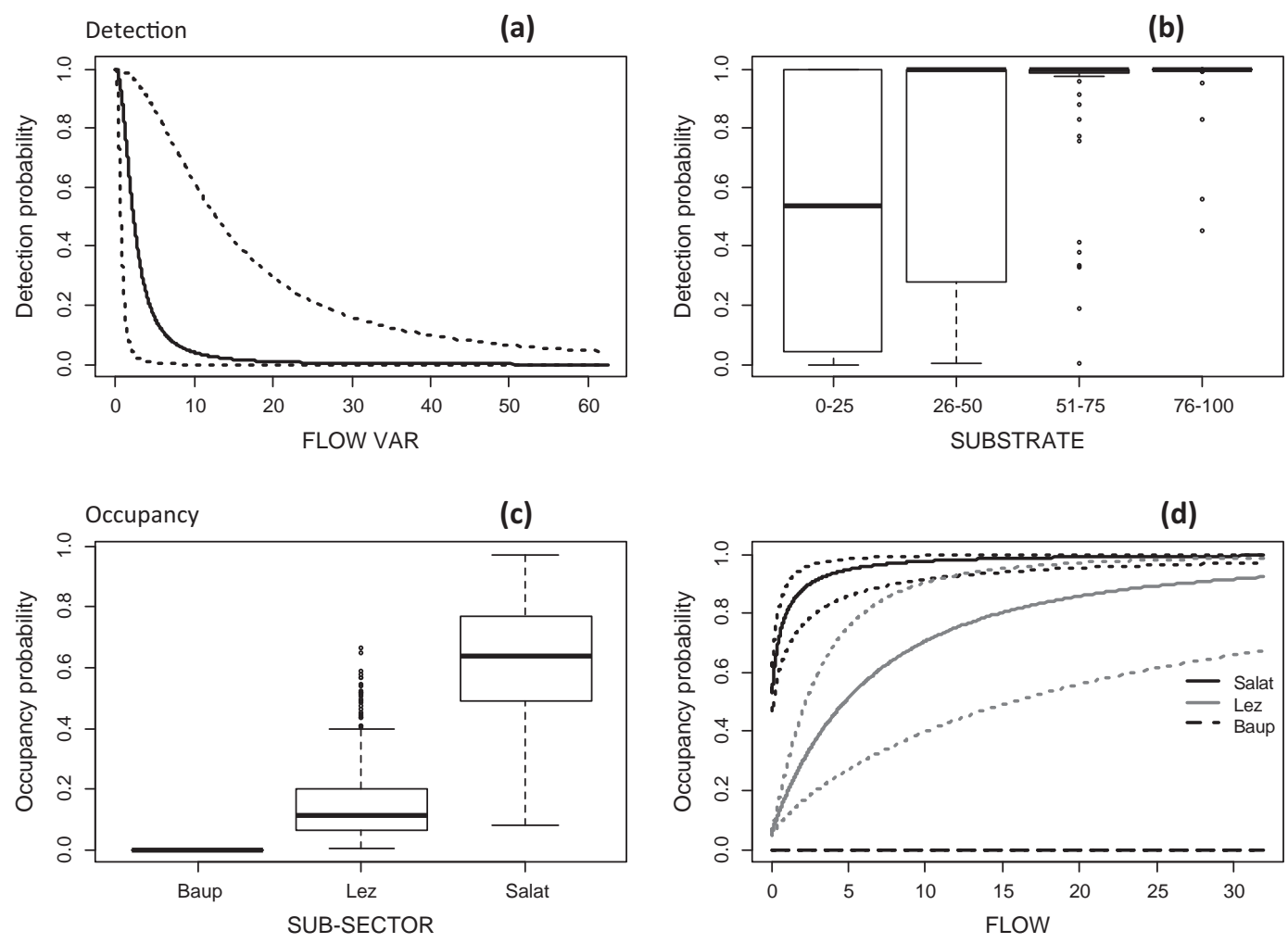

(d)

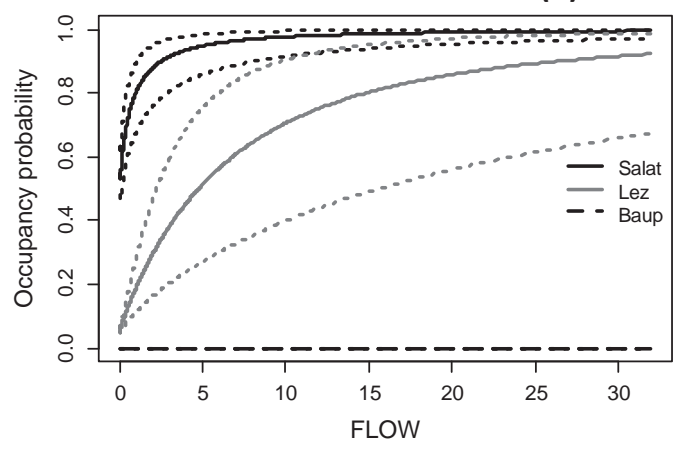

(e)

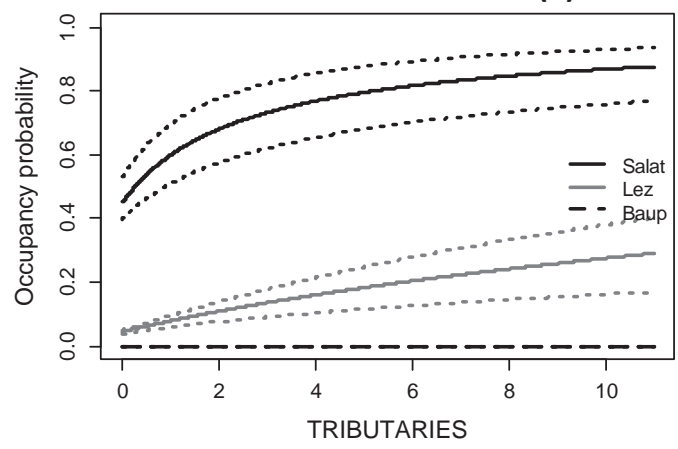

(f)

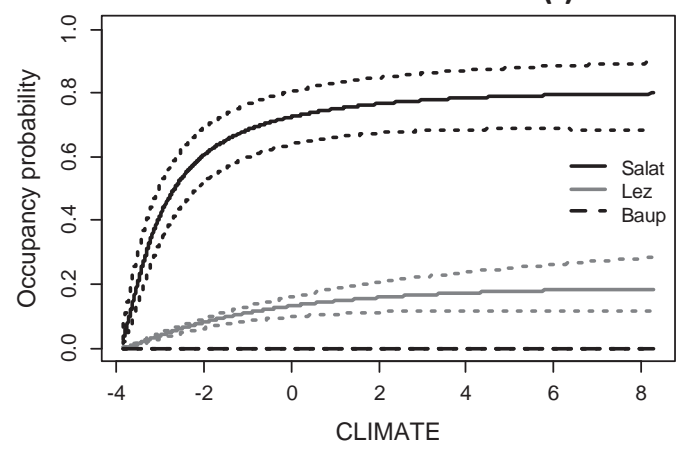

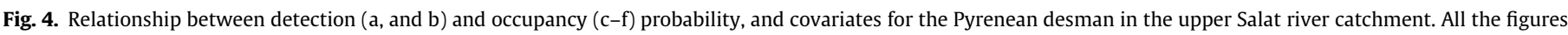

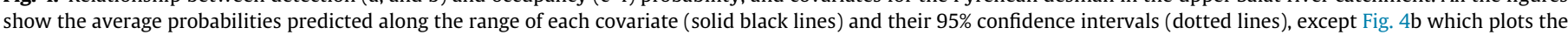

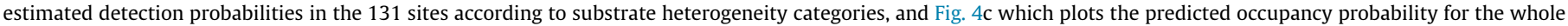
study area (1388 1-km long sections) according to the sub-sector. Predictions were computed with the other covariates at their mean values.

suggested a preference of this species for fast flowing waters (Nores et al., 1992; Queiroz et al., 1993, 1996; Ramalhinho and Boa Vida, 1993). One hypothesis to explain this preference for high water flow in mountainous regions would be that abundance and richness of invertebrates, which are the main prey of the Pyrenean desman (Bertrand, 1994), are known to be positively related to flow (Aymerich, 2004; Dewson et al., 2007). This finding is also in accordance with Nores et al. (1992) who suggested that the factors that influence the Pyrenean desman the most are those related to hydrology characteristics. They proposed a rather mechanical explanation for this preference arguing that high water velocity may help the desman float in the water for optimal use of its resources. Nores et al. (1992) found that the presence of the Pyrenean desman was favoured for a water velocity greater than $0.2 \mathrm{~m} /$ s. In our study, highest occupancy was obtained for river transects with flow above $5 \mathrm{~m}^{3} / \mathrm{s}$ and $15 \mathrm{~m}^{3} / \mathrm{s}$ in the Salat and Lez subsectors, respectively. But, we can observe that for these two subsectors, the most rapid increase of occupancy is obtained up to
$5 \mathrm{~m}^{3} / \mathrm{s}$, and grows beyond this value much more slowly, meaning that this species can tolerate quite high flow. On a larger scale (e.g. Iberian Peninsula), Barbosa et al. (2003) and Morueta-Holme et al. (2010) highlighted the importance of water abundance, owing to the amphibious lifestyle of the Pyrenean desman, as more water offers better habitat conditions and greater food availability. As suggested by Aymerich (2004), artificial reduction of flow regime (e.g. due to hydropower production or irrigation) likely has a negative impact on Pyrenean desman occurrence, especially in mountain rivers which are more sensitive to flow reduction. Our results also revealed the positive influence of the number of tributaries on the presence of the Pyrenean desman. A high number of tributaries may act as refuge areas in case of natural or artificial flooding (Lake, 2000), which can facilitate the recolonization of disturbed sites by the species. The strong influence of the geographic area that we found may indicate that Pyrenean desman occurrences show spatial clustering, with an influence of terrestrial barriers, and that dispersal is mainly constrained by aquatic 

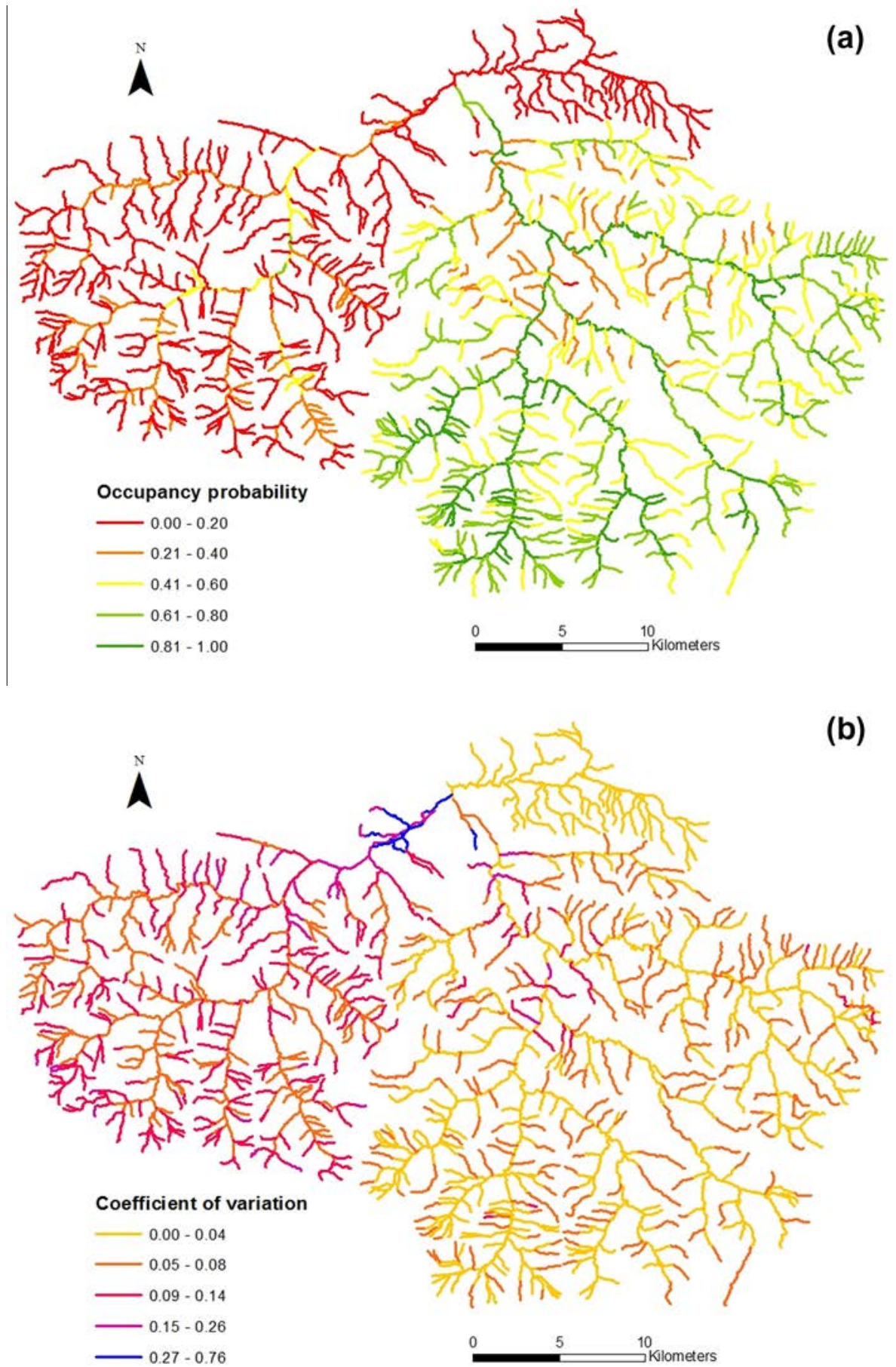

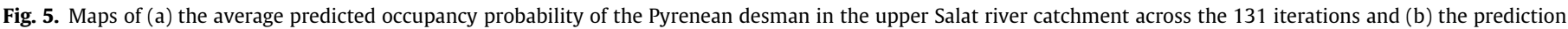

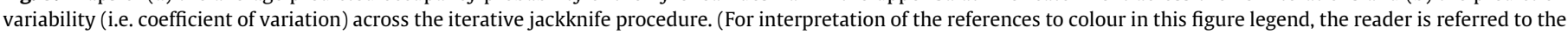
web version of this article.)

environments (Filipe et al., 2009). Spatial structuring of distribution for other semi-aquatic species less restricted to aquatic habitats, such as the European otter (Lutra lutra), has already been emphasized and is thought to result from population dynamics (Barbosa et al., 2003). We never found Pyrenean desman faeces in the Baup catchment, which we assume to be caused by extremely low sign detection or possible extirpation of desman from this area due to unsuitable environmental conditions within this catchment (i.e. agricultural land, drier and warmer climate). The spatial clustering of Pyrenean desman occurrences and the high probability of suitable habitats in the Salat sub-sector both suggest that this area may represent one large population connected by movement and gene flow. Stream connectivity should thus be favoured as habitat fragmentation could potentially decrease demographic support for tributaries and lead to isolation of populations, as mentioned by Nores et al. (1999) and Queiroz et al. (1996). Until more data on movement and dispersal of the Pyrenean desman are available, the most cautious conservation strategy is thus to protect habitat quality and connectivity throughout the entire sub-sector. The predicted occupancy map would therefore be useful as a decision-making instrument for future developments within this catchment. 
Lastly, studies previously conducted on a larger scale revealed the importance of climate to explain the Pyrenean desman distribution. Indeed, it has been shown that mean annual precipitation has a positive influence and annual air temperature a negative influence in Spain and Portugal (Barbosa et al., 2009, 2010; Morueta-Holme et al., 2010). By contrast, a negative relationship between precipitation and the presence of Pyrenean desman as well as a positive relationship with air temperature were found in France (Williams-Tripp et al., 2012). At a finer scale (i.e. catchment scale), we found a pattern similar to that reported in Spain and Portugal, but our results suggest that climatic variables appear to be much less influential than the three other covariates considered. This contrasted result is consistent with the fact that hydrology is known to be more important in structuring the distribution of aquatic species within the species range than climate which drives spatial distribution at larger scales (Bucklin et al., 2015; Morueta-Holme et al., 2010).

\subsection{Better accounting for the hydrology when modelling the distribution of aquatic species}

In aquatic ecosystems, abiotic factors that structure freshwater species distribution are different from those that influence species in terrestrial environments (Jähnig et al., 2012). However, hydrological variables are rarely taken into account into SDMs due to a lack of detailed data for the whole study area. Applying SDMs at fine scales (e.g. catchment scale) may result in an incomplete description of species ecological niche (Ottaviani et al., 2009) as these factors are known to strongly influence the distribution of freshwater species. Hence, as mentioned by Jähnig et al. (2012), integrated modelling approaches are needed to provide habitat suitability predictions of aquatic organisms using adequate predictors. Some hydrological models such as the SWAT model make it possible to simulate stream flow across an entire stream network and then to use flow as an input variable in SDMs. For example, by using hydrological and hydraulic models, Jähnig et al. (2012) simulated water levels, flow velocities and sediment processes in a river section, to serve as inputs into an SDM applied to a freshwater mollusc. All these hydrological and hydraulic parameters appeared to explain significantly its occurrence. Moreover, Kuemmerlen et al. (2014) used SWAT to simulate hydrological factors (e.g. flow seasonality, flow range) and applied SDMs to invertebrate species at the catchment scale. They showed more accurate predictions of habitat suitability when hydrological factors were included among the predictors. Coupling between a hydrological model and SDMs thus appears promising to get more accurate predictions of species distribution from SDMs in freshwater ecosystems at fine resolution (Kuemmerlen et al., 2014). This should be applied to a wider range of aquatic and semi-aquatic species (e.g. mammals, birds, reptiles, amphibians, fish, stream invertebrates), especially for studies at local scales to improve ecological knowledge about these species.

\subsection{Accounting for the imperfect detection of species}

A major issue in monitoring wild animal populations is the difficulty to detect species. This problem can be taken into account using occupancy models to avoid false absence data (MacKenzie et al., 2006). The value of these statistical methods has been largely acknowledged during the last few years with many applications for a wide diversity of species such as insects (Kéry et al., 2010), fish (Comte and Grenouillet, 2013), reptiles (Durso et al., 2011) and birds (Kéry et al., 2013). In our study, in spite of quite high detection probabilities found for the Pyrenean desman, the use of a site-occupancy model has limited the risk of underestimating the Pyrenean desman occupancy. More generally, occupancy models may avoid introducing errors into distribution patterns (Comte and Grenouillet, 2013) or introducing bias into wildlifehabitat relationships (Gu and Swihart, 2004; Kéry et al., 2010), two issues that are crucial for species with low detectability. Indeed, for rare, secretive or nocturnal species, it may be difficult to detect individuals visually and logistics constraints may appear for surveys in rough terrain (Aing et al., 2011). Consequently, survey methods based on recording indirect signs have become standard practice for many species (Heinemeyer et al., 2008). Depending on the species ecology, if the data are based on sign surveys and sampled following a design with spatially adjacent replicates, they could be analyzed with the Markovian occupancy model. This may concern species that use trails to move as do many large mammals (Barber-Meyer et al., 2013; Karanth et al., 2011; Thorn et al., 2011), using a linear home range (e.g. species living along rivers or ecotones) or species for which surveys follow a linear configuration (e.g. roads, trails) such as those carried out in remote systems (e.g. mountains, forests). Moreover, spatially adjacent replicates have the advantage of being more effective and straightforward to implement than temporal replication (see Charbonnel et al., 2014 for more details).

Whereas the importance of accounting for false negative errors is frequently recognized, much less attention has however been given to false positives (Miller et al., 2011). A specific occupancy model developed by Royle and Link (2006) can account for false positives when genetic analyses are too expensive and not appropriate for some survey techniques (e.g. listening points). In our case, DNA analyses were appropriate to avoid false positives that would have occurred by misidentifying the faeces of other species (e.g. Neomys spp., Glis spp., Myotis spp, Turdus spp., Pordarcis spp.) as being Pyrenean desman. For species with shrinking ranges, false-positive observations may thus result in an underestimation of the population decline. However, the use of modern DNA techniques makes sure that a faeces sample belongs to the species of interest, thus resulting in a reduced risk of overestimating occupancy probabilities. Given the serious consequences of inaccurate estimates of the status of rare species for conservation and management decisions, accounting for false-positive errors should be an important component when designing and analyzing monitoring programs for rare species (Miller et al., 2011) or species for which surveys are based on the recording of indirect cues (e.g. scats) like many carnivore species (Heinemeyer et al., 2008).

\section{Acknowledgements}

We thank all the field investigators who helped for the field work: R. Lassus, F. Julien, F. Gilbert, S. Perré and A. Denis. We are also grateful to SWAT modellers for their precious help: Y. Grusson, A. Uhart, X. Sun, J. Payoux, as well as the R modeller A. Maire, and J. Brown and M. Williams-Tripp for the implementation of the GRTS sampling. Thank to S. Danflous who corrected the English text, and the Parc Naturel Régional des Pyrénées ariégeoises for the availability of the land use database (BDOS (c) 2013). This study was funded by ANRT (Cifre $n^{\circ}$ 2011/1018), EDF (Electricité de France) and European Union (FEDER) and is part of the French conservation Action Plan for the Pyrenean desman (2010-2015) supervised by DREAL MP (Direction Régionale pour l'Environnement, l'Aménagement et le Logement de Midi-Pyrénées) and coordinated by the CEN MP (Conservatoire d'Espaces Naturels Midi-Pyrénées).

\section{Appendix A. Supplementary material}

Supplementary data associated with this article can be found, in the online version, at http://dx.doi.org/10.1016/j.biocon.2015.01. 019. 


\section{References}

Aing, C., Halls, S., Oken, K., Dobrow, R., Fieberg, J., 2011. A Bayesian hierarchical occupancy model for track surveys conducted in a series of linear, spatially correlated, sites. J. Appl. Ecol. 48, 1508-1517.

Allan, J.D., Palmer, M., Poff, N.L., 2005. Climate change and freshwater ecosystems. In: Lovejoy, T.E., Hannah, L. (Eds.), Climate Change and Biodiversity. Yale University Press, pp. 274-290.

Arnold, J.G., Srinivasan, R., Muttiah, R.S., Williams, J.R., 1998. Large area hydrologic modeling and assessment Part I: model development. J. Am. Water Resour. Assoc. 34, 73-89.

Aymerich, P., 2004. Els micromamifers semiaquatics d'Andorra: distribucio i estat de conservacio. Habitats 9, 26-34.

Aymerich, P., Gosàlbez, J., 2004. La prospección de excrementos como metodología para el estudio de la distribución de los musgaños. Galemys: Boletín informativo de la Sociedad Española para la conservación y estudio de los mamíferos, vol. 16, pp. 83-90.

Barber-Meyer, S.M., Jnawali, S.R., Karki, J.B., Khanal, P., Lohani, S., Long, B. MacKenzie, D.I., Pandav, B., Pradhan, N.M.B., Shrestha, R., Subedi, N., Thapa, G., Thapa, K., Wikramanayake, E., 2013. Influence of prey depletion and human disturbance on tiger occupancy in Nepal. J. Zool. 289, 10-18.

Barbosa, A.M., Real, R., Olivero, J., Vargas, J.M., 2003. Otter (Lutra lutra) distribution modeling at two resolution scales suited to conservation planning in the Iberian Peninsula. Biol. Conserv. 114 (377), 387.

Barbosa, A.M., Real, R., Vargas, J.M., 2009. Transferability of environmental favourability models in geographic space: The case of the Iberian desman (Galemys pyrenaicus) in Portugal and Spain. Ecol. Model. 220, 747-754.

Barbosa, A.M., Real, R., Vargas, J.M., 2010. Use of coarse-resolution models of species' distributions to guide local conservation inferences. Conserv. Biol. 24 $1378-1387$.

Bertrand, A., 1994. Répartition géographique et écologie alimentaire du desman des Pyrénées Galemys pyrenaicus (Geoffroy, 1811) dans les Pyrénées françaises. Diplôme Universitaire de Recherche, Toulouse.

Blank, L., Blaustein, L., 2012. Using ecological niche modeling to predict the distributions of two endangered amphibian species in aquatic breeding sites. Hydrobiologia 693, 157-167.

Bucklin, D.N., Basille, M., Benscoter, A.M., Brandt, L.A., Mazzotti, F.J., Romañach, S.S. Speroterra, C., Watling, J.I., 2015. Comparing species distribution models constructed with different subsets of environmental predictors. Divers. Distrib. 21, 23-35.

Burnham, K.P., Anderson, D.R., 2002. Model selection and multi-model inference: a practical information-theoretic approach. Springer, New York, NY.

Charbonnel, A., D’Amico, F., Besnard, A., Blanc, F., Buisson, L., Némoz, M., Laffaille, P., 2014. Spatial replicates as an alternative to temporal replicates for occupancy modelling when surveys are based on linear features of the landscape. J. Appl. Ecol. 51, 1425-1433.

Comte, L., Grenouillet, G., 2013. Species distribution modelling and imperfect detection: comparing occupancy versus consensus methods. Divers. Distrib. 19, 996-1007.

Dewson, Z.S., James, A.B.W., Death, R.G., 2007. A review of the consequences of decreased flow for instream habitat and macroinvertebrates. J. North Am. Benthol. Soc. 26, 401-415.

Domisch, S., Araújo, M.B., Bonada, N., Pauls, S.U., Jähnig, S.C., Haase, P., 2013. Modelling distribution in European stream macroinvertebrates under future climates. Glob. Change Biol. 19, 752-762.

Dudgeon, D., Arthington, A.H., Gessner, M.O., Kawabata, Z.-I., Knowler, D.J., Lévêque C., Naiman, R.J., Prieur-Richard, A.-H., Soto, D., Stiassny, M.L.J., Sullivan, C.A., 2006. Freshwater biodiversity: importance, threats, status and conservation challenges. Biol. Rev. 81, 163-182.

Durso, A.M., Willson, J.D., Winne, C.T., 2011. Needles in haystacks: estimating detection probability and occupancy of rare and cryptic snakes. Biol. Conserv. $144,1508-1515$

Fernandes, M., Herrero, J., Aulagnier, S., Amori, G., 2008. Galemys pyrenaicus. In: IUCN 2012. IUCN Red List of Threatened Species. Version 2012.2. <http://www iucnredlist.org>. Downloaded on 20 March 2013.

Filipe, A.F., Araújo, M.B., Doadrio, I., Angermeier, P.L., Collares-Pereira, M.J., 2009. Biogeography of Iberian freshwater fishes revisited: the roles of historical versus contemporary constraints. J. Biogeogr. 36, 2096-2110.

Gassman, P.W., Reyes, M.R., Green, C.H., Arnold, J.G., 2007. The soil and wate assessment tool: historical development, applications, and future research directions. Trans. Am. Soc. Agric. Biol. Eng. 50, 1211-1250.

Gillet, F., Cabria Garrido, M. T., Némoz, M., Blanc, F., Fournier-Chambrillon, C., Sourp, E., Vial-Novella, C., Aulagnier, S., Michaux, J., in press. PCR-RFLP identification of the endangered Pyrenean desman, Galemys pyrenaicus (Soricomorpha, Talpidae), based on faecal DNA. Mammalia.

González-Esteban, J., Villate, I., Castién, E., 2003. A comparison of methodologies used in the detection of the Pyrenean desman Galemys pyrenaicus (E. Geoffroy, 1811). Mammalian Biol. 68, 387-390.

Gu, W., Swihart, R.K., 2004. Absent or undetected? Effects of non-detection of species occurrence on wildlife-habitat models. Biol. Conserv. 116, 195-203.

Guisan, A., Zimmermann, N.E., 2000. Predictive habitat distribution models in ecology. Ecol. Model. 135, 147-186.

Habets, F., Boone, A., Champeaux, J.L., Etchevers, P., Franchistéguy, L., Leblois, E., Ledoux, E., Le Moigne, P., Martin, E., Morel, S., Noilhan, J., Quintana Seguí, P.,
Rousset-Regimbeau, Viennot, P., . The SAFRAN-ISBA-MODCOU hydrometeorological model applied over France. J. Geophys. Res. 113, 1-18.

Heinemeyer, K.S., Ulizio, T.J., Harrison, R.L., 2008. Natural sign: tracks and scat. In: Long, R.A., MacKay, P., Zielinski, W.J., Ray, J.C. (Eds.), Non-Invasive Survey Methods for Carnivores. Island Press, Washington, DC, pp. 45-74.

Hines, J.E., 2006. PRESENCE 2: software to estimate patch occupancy and related parameters. U.S. Geological Survey, Patuxent Wildlife Research Center, Laurel, Maryland, USA. <http://www.mbr-pwrc.usgs.gov/software/presence.htmli>

Hines, J.E., Nichols, J.D., Royle, J.A., MacKenzie, D.I., Gopalaswamy, A.M., Kumar, N.S., Karanth, K.U., 2010. Tigers on trails: occupancy modeling for cluster sampling. Ecol. Appl. 20, 1456-1466.

Jähnig, S.C., Kuemmerlen, M., Kiesel, J., Domisch, S., Cai, O., Schmalz, B., Fohrer, N., 2012. Modelling of riverine ecosystems by integrating models: conceptual approach, a case study and research agenda. J. Biogeogr. 39, 2253-2263.

Karanth, K.U., Gopalaswamy, A.M., Kumar, N.S., Vaidyanathan, S., Nichols, J.D., MacKenzie, D.I., 2011. Monitoring carnivore populations at the landscape scale: occupancy modelling of tigers from sign surveys. J. Appl. Ecol. 48, 1048-1056.

Kéry, M., Gardner, B., Monnerat, C., 2010. Predicting species distributions from checklist data using site-occupancy models. J. Biogeogr. 37, 1851-1862.

Kéry, M., Guillera-Arroita, G., Lahoz-Monfort, J.J., 2013. Analysing and mapping species range dynamics using occupancy models. J. Biogeogr. 40, 1463-1474.

Kiesel, J., Fohrer, N., Schmalz, B., White, M.J., 2010. Incorporating landscape depressions and tile drainages of a northern German lowland catchment into a semi-distributed model. Hydrol. Process. 24, 1472-1486.

Kuemmerlen, M., Schmalz, B., Guse, B., Cai, Q., Fohrer, N., Jähnig, S.C., 2014. Integrating catchment properties in small scale species distribution models of stream macroinvertebrates. Ecol. Model. 277, 77-86.

Lake, P.S., 2000. Disturbance, patchiness, and diversity in streams. J. North Am. Benthol. Soc. 19, 573-592.

MacKenzie, D.I., Nichols, J.D., Lachman, G.B., Droege, S., Royle, J.A., Langtimm, C.A., 2002. Estimating site occupancy rates when detection probabilities are less than one. Ecology 83, 2248-2255.

MacKenzie, D.I., Nichols, J.D., Royle, J.A., Pollock, K.H., Bailey, L.L., Hines, J.E., 2006. Occupancy Estimation and Modeling: Inferring Patterns and Dynamics of Species Occurrence. Academic Press, Burlington, Massachusetts, USA.

Manel, S., Williams, H.C., Ormerod, S.J., 2001. Evaluating presence absence models in ecology: the need to account for prevalence. J. Appl. Ecol. 38, 921-931.

Melero, Y., Aymerich, P., Luque-Larena, J.J., Gosàlbez, J., 2012. New insights into social and space use behaviour of the endangered Pyrenean desman (Galemys pyrenaicus). Eur. J. Wildl. Res. 58, 185-193.

Miller, D.A., Nichols, J.D., McClintock, B.T., Grant, E.H.C., Bailey, L.L., Weir, L.A., 2011. Improving occupancy estimation when two types of observational error occur: non-detection and species misidentification. Ecology 92, 1422-1428.

Moriasi, D.N., Arnold, J.G., Van Liew, M.W., Binger, R.L., Harmel, R.D., Veith, T., 2007. Model evaluation guidelines for systematic quantification of accuracy in watershed simulations. Trans. ASABE 50 (3), 885-900.

Morueta-Holme, N., Flojgaard, C., Svenning, J.-C., 2010. Climate change risks and conservation implications for a threatened small-range mammal species. PLoS ONE 5, e10360.

Némoz, M., Bertrand, A., Sourie, M., Arlot, P., 2011. A French Conservation Action Plan for the Pyrenean Desman Galemys pyrenaicus. Galemys: Boletín informativo de la Sociedad Española para la conservación y estudio de los mamíferos, vol. 23, pp. 47-50.

Neitsch, S.L., Arnold, J.G., Kiniry, J.R., Williams, J.R., 2005. Soil and Water Assessment Tool Theoretical Documentation, Version 2013. Temple, Tex.: USDA-ARS Grassland, Soil and Water Research Laboratory. <http://www.brc.tamus.edu/ swat/doc.html> (accessed 01.05.13).

Nores, C., Ojeda, F., Ruano, A., Villate, I., González, J., 1992. Aproximación a la metodología y estudio del área de distribución, estatus de población y selección de hábitat del desmán (Galemys pyrenaicus) en la Península Ibérica. Ministerio de Medio Ambiente, Oviedo.

Nores, C, Palacios, B., Ventura, J.A.M., Vàzquez, V.M., González, J., et al., 1999. Informe sobre la situación del Desmán Ibérico (Galemys pyrenaicus) en España. Seminariode conservación de argaritifera margaritifera y Galemys pyrenaicus en la Península Ibérica, Pola de Somiedo (Asturias, Spain).

Ottaviani, D., Panzacchi, M., Jona Lasinio, G., Genovesi, P., Boitani, L., 2009. Modelling semi-aquatic vertebrates' distribution at the drainage basin scale: the case of the otter Lutra lutra in Italy. Ecol. Model. 220, 111-121.

Pagé, C., Terray, L., 2010. Nouvelles projections climatiques à échelle fine sur la France pour le 21ème siècle : les scénarii SCRATCH2010. Technical Report TR/ CMGC/10/58, SUC au CERFACS, URA CERFACS/CNRS No1875CS, Toulouse, France.

Palmeirim, J.M., Hoffmann, R.S., 1983. Galemys pyrenaicus. Mammalian Species 207, 1-5.

Pedroso, N.M. Marques, T.A. Santos-Reis, M., 2014. The response of otters to environmental changes imposed by the construction of large dams. Aquatic Conserv.: Marine Freshwater Ecosyst. 24, 66-80.

Queiroz, A.I., Alves, H., Almada, V., 1993. The small hydro plants: predicted impacts on the Pyrenean desman populations (Galemys pyrenaicus, Geoffroy). In: Proceedings of the Meeting on the Pyrenean Desman, Lisbon, pp. 69-77.

Qi, C., Grunwald, S., 2005. GIS-based hydrologic modeling in the Sandusky watershed using SWAT. Trans. ASABE 48, 169-180.

Queiroz, A.I., Bertrand, A., Khakhin, G., 1996. Status and conservation of Desmaninae in Europe. Council of Europe, Strasbourg. 
Ramalhinho, M.G., Boa Vida, M.J., 1993. Habitat of the Pyrenean Desman: assessment of running water quality. Monitoring pollution. In: Proceedings of the Meeting on the Pyrenean Desman, Lisbon, pp. 63-67

Reid, N., Lundy, M.G., Hayden, B., Lynn, D., Marnell, F., McDonald, R.A., Montgomery, W.I., 2013. Detecting detectability: identifying and correcting bias in binary wildlife surveys demonstrates their potential impact on conservation assessments. Eur. J. Wildl. Res. 59, 869-879.

Royan, A., Hannah, M.D., Reynolds, J.S., Noble, G.D., Sadler, P.J., 2014. River birds' response to hydrological extremes: new vulnerability index and conservation implications. Biol. Conserv. 177, 64-73.

Royle, J.A., Link, W.A., 2006. Generalized site occupancy models allowing for false positive and false negative errors. Ecology 87, 835-841.

Stevens, D.L., Olsen, A.R., 2004. Spatially balanced sampling of natural resources. J. Am. Stat. Assoc. 99, 262-278.

Strayer, D.L., Dudgeon, D.D., 2010. Freshwater biodiversity conservation: recent progress and future challenges. J. North Am. Benthol. Soc. 29, 344-358.

Thorn, M., Green, M., Bateman, P.W., Waite, S., Scott, D.M., 2011. Brown hyaenas on roads: Estimating carnivore occupancy and abundance using spatially autocorrelated sign survey replicates. Biol. Conserv. 144, 1799-1807.
Toner, J., Farrell, J., Mead, J., 2010. Muskrat abundance responses to water level regulation within freshwater coastal wetlands. Wetlands 30, 211-219.

Vörösmarty, C.J., McIntyre, P.B., Gessner, M.O., Dudgeon, D., Prusevich, A., Green, P., Glidden, S., Bunn, S.E., Sullivan, C.A., Liermann, C.R., Davies, P.M., 2010. Global threats to human water security and river biodiversity. Nature 467, 555-561.

Williams-Tripp, M., D’Amico, F.J.N., Pagé, C., Bertrand, A., Némoz, M., Brown, J.A., 2012. Modeling rare species distribution at the edge: the case for the vulnerable endemic Pyrenean desman in France. Scientific World J. 2012, 1-6.

Waits, L.P., Paetkau, D., 2005. Noninvasive genetic sampling tools for wildlife biologists: a review of applications and recommendations for accurate data collection. J. Wildl. Manag. 69, 1419-1433.

Winchell, M., Srinivasan, R., Di Luzio, M., Arnold, J.G., 2007. ArcSWAT interface for SWAT user's guide. Blackland Research Center, Texas Agricultural Experiment Station and USDA Agricultural Research Service. 